\section{Weed Management, Training, and Irrigation Practices for Organic Production of Trailing Blackberry: I. Mature Plant Growth and Fruit Production}

\author{
Emily K. Dixon ${ }^{1}$, Bernadine C. Strik ${ }^{2,3}$, and Luis R. Valenzuela-Estrada \\ Department of Horticulture, Oregon State University, 4017 ALS, Corvallis, \\ OR 97331 \\ David R. Bryla \\ U.S. Department of Agriculture, Agricultural Research Service, Horticultural \\ Crop Research Unit, 3420 NW Orchard Avenue, Corvallis, OR 97330
}

Additional index words. drip irrigation, landscape fabric, leaf water potential, weed mat, Rubus, yield, cold hardiness, raspberry crown borer

\begin{abstract}
Weed management, training time, and irrigation practices were evaluated from 2013 to 2014 in a mature field of trailing blackberry (Rubus L. subgenus Rubus Watson) established in western Oregon. The field was planted in 2010 and certified organic in 2012, before the first harvest season. Treatments included two cultivars (Marion and Black Diamond), three weed management practices [nonweeded, hand-weeded or bare soil, and weed mat (black landscape fabric)], two irrigation strategies (irrigation throughout the growing season and no postharvest irrigation), and two primocane training dates (August and February). When averaged over the other treatments, 'Marion' and 'Black Diamond' had similar yields in both years. However, the presence of weeds reduced vegetative growth and yield, especially in 'Black Diamond', while weed mat increased growth and yield over hand-weeded plots by $13 \%$. Withholding irrigation after harvest reduced water use by an average of $44 \%$ each year without adversely affecting yield in either cultivar. The effects of training time were primarily seen in 2014 after a cold winter. August-trained 'Marion' plants had more cold damage than February-trained plants and, consequently, had fewer and shorter canes, less biomass, fewer nodes, and $1 \mathrm{~kg} / \mathrm{plant}$ less yield than February-trained plants. 'Black Diamond' was cold hardier than 'Marion', but was more readily infested by raspberry crown borer (Pennisetia marginata Harris). As the planting reached maturity, yields in the best performing organic production systems (both cultivars under weed mat and 'Marion' that was February-trained) averaged 11 and 9 t.ha ${ }^{-1}$, for 'Black Diamond' and 'Marion' respectively, similar to what would be expected in conventional production.
\end{abstract}

About 6000 ha of blackberry (Rubus L. subgenus Rubus, Watson) was harvested in the United States in 2012 [U.S. Department of Agriculture (USDA), 2014]. Oregon was the leading producer with 2500 ha, most of which were trailing types grown predominantly for the processed market (Strik and Finn, 2012; USDA, 2014). There were only

\footnotetext{
Received for publication 30 Apr. 2015. Accepted for publication 2 June 2015.

We appreciate research funding support provided by the Northwest Center for Small Fruits Research, the USDA National Institute of Food and Agriculture (Formula Grant no. OREI 2010-01940; ORE00409), our industry contributors, and the technical assistance provided by Gil Buller and Amanda Vance. ${ }^{1}$ From the M.S. thesis of E.K. Dixon.

${ }^{2}$ Professor.

${ }^{3}$ Corresponding author. E-mail: bernadine.strik@ oregonstate.edu.
}

200 ha of organic blackberry harvested from certified and exempt organic farms in the United States in 2008, although worldwide production was 2500 ha (Strik et al., 2008; USDA, 2010). Consumer demand for organic products has been steadily increasing, creating a price premium for organic fruit and strong interest in organic production systems.

There is a growing body of research dedicated to blackberry growth and production (e.g., Strik and Finn, 2012), but there has been relatively little published on the organic production of blackberry. The Appropriate Technology Transfer for Rural America has published a general organic production guide that is mainly focused on small-scale production of erect and semierect types of blackberry for the fresh market with little information on the production of trailing types for the processed market (Kuepper et al., 2003). In organic trailing blackberry systems, Harkins et al.
(2013, 2014) studied weed management and cultivar impacts during establishment, and Fernandez-Salvador et al. (2015a, 2015b) investigated several cultivar and fertilizer options.

Weed management can be one of the most challenging and expensive issues to address in organic production, as Organic Materials Review Institute (OMRI)-listed materials for weed control are limited, and removing weeds by hand is expensive. Therefore, some growers allow weeds to grow in organic blackberry plantings and remove them only before harvest. However, weeds compete with blackberry plants and can significantly reduce yield when left unmanaged (Harkins et al., 2013; Meyers et al., 2014). The use of a perforated landscape fabric, or "weed mat," as a barrier to weeds within the blackberry row has been successful in blackberry plantings during establishment (Harkins et al., 2013; Makus, 2011; Meyers et al., 2014).

Most of the research published to date on trailing blackberry has been in 'Marion' or other older cultivars (Bell et al., 1995a, 1995b; Cortell et al., 1997a, 1997b; Julian et al., 2009; Mohadjer et al., 2001; Sheets et al., 1972; Takeda et al., 2002). However, many newer thornless cultivars, such as 'Black Diamond', are desirable to producers because they reduce training time and cane damage and eliminate the risk of finding thorny petioles in the machine-harvested, processed end product (Strik and Buller, 2002). Thornless cultivars of trailing blackberry are also reported to be cold hardier (Finn et al., 2005). 'Marion' and 'Black Diamond' together accounted for $>75 \%$ of the 2914 ha of blackberry produced in Oregon in 2012 (USDA, 2013).

Trailing blackberry canes are typically trained onto a two-wire trellis in either late summer or late winter. Bell et al. (1995a) found that 'Marion' plants trained in August produced $46 \%$ greater yield than those trained in February. Despite the potential increase in yield, many growers still train in February, as canes left on the ground through the colder winter months are better protected from cold damage (Bell et al., 1992).

Irrigation practices in blackberry are varied. Most fresh market plantings are irrigated by drip irrigation, while blackberry grown for processed markets are most commonly irrigated using moveable pipe with overhead sprinklers or big gun systems (Strik and Finn, 2012; B.C. Strik, personal observation). Some growers in Oregon do not irrigate at all, even though blackberry plants have high water demands during fruit production (Bryla and Strik, 2008; Strik and Finn, 2012) and there is relatively little precipitation in summer (U.S. Department of Interior, 2013). There may be an option for an intermediate solution of turning off irrigation to blackberry after harvest instead of irrigating throughout the summer because irrigation demand drops off after fruit production (Bryla and Strik, 2008). Drip irrigation may be especially beneficial in organic production by reducing weed presence outside the drip zone and disease problems in the canopy when compared with overhead systems. 
Applying fertilizers through the drip irrigation system (fertigation) has worked well using OMRI-approved products in organic blackberry (Fernandez-Salvador et al., 2015a).

The objective of this study was to evaluate various production practices (cultivar, weed management, training time, and irrigation) for their effect on growth and organic production of mature trailing blackberry that were machine-harvested for the processed market. Two cultivars, 'Marion' and 'Black Diamond', were included in the study, along with three weed management strategies, nonweeded, hand-weeded, and weed mat. Two training dates, August and February, and two irrigation strategies, continuous summer irrigation and no irrigation after fruit harvest, were also included.

\section{Materials and Methods}

Study site. The study was carried out in 2013 and 2014 in a mature trailing blackberry planting at the North Willamette Research and Extension Center in Aurora, OR [latitude $45^{\circ} 16^{\prime} 47^{\prime \prime} \mathrm{N}$, longitude $122^{\circ} 45^{\prime} 23^{\prime \prime} \mathrm{W}$; USDA hardiness zone $8 \mathrm{~b}$ (U.S. Department of Interior, 2013); elevation $56 \mathrm{~m}]$. The soil is a Willamette silt loam, classified as a fine-silty, mixed, superactive mesic Pachic Ultic Argixeroll. The site was certified as organic by a USDAaccredited agency (Oregon Tilth, Certified Organic, Corvallis, OR).

The field was planted with tissue-cultured plug plants on 26 May 2010. Annual development of the planting during establishment was described by Harkins et al. (2013). Plants were trained on a two-wire vertical trellis system in each row with the wires attached to steel posts at 1.0 and $1.6 \mathrm{~m}$ above the ground. Primocanes that grew in year 1 (2010, the planting year) were removed in the following winter (Feb. 2011) to increase subsequent growth and promote plant establishment, as per standard commercial practice (Strik and Finn, 2012). In year 2 (2011), primocanes were trained to the trellis wires as they grew. By year 3 (2012, the first fruiting season) through year 5 (2014), plants had primocanes and floricanes (the previous year's primocanes). New primocanes were bundled and tied to the bottom trellis wire, below the floricane canopy, until August each year. Primocanes were then trained to the upper trellis wires in late August or February, depending on treatment (see "Primocane training" below), by dividing the primocanes produced by each plant into two bundles and looping half in one direction from the upper to middle trellis wire and bringing it back toward the plant with one or two twists; the other half was looped in the opposite direction. An every-year production system was chosen because it is the predominant production method used by growers (Strik and Finn, 2012). Refer to the work by Harkins et al. (2013) for further details on site preparation and establishment.

Experimental design. Treatments were arranged as a split-split-split plot design with five replicates and included a row of 'Marion' and a row of 'Black Diamond' blackberry as main plots, two irrigation strategies (postharvest and no postharvest irrigation) as split plots, and a combination of three weed management strategies (weed mat, hand-weeded, and nonweeded), and two primocane training dates (August and February) as split-split plots. Each split-split plot consisted of four plants spaced $1.5 \mathrm{~m}$ apart in-row and was separated from plants in adjacent plots by $3.0 \mathrm{~m}$ (to provide space for clearing the machine harvester). In-between row spacing was $3.0 \mathrm{~m}$ (2222 plants/ha). The planting also had a plot of four border plants at the end of each row, and a border row on each side. Overall, there were 12 rows of $104 \mathrm{~m}$ each (0.4 ha) and a total of 120 treatment plots.

Weed management. The three weed management strategies were applied to each plot individually. Weeds were only removed from the nonweeded plots during the first year after planting (2010) to aid in plant establishment. In subsequent years, weeds in the nonweeded plots were cut to soil level just before machine harvest (early July) to avoid any interference with the catcher plates. The biomass removed was left in the row except for a $0.25 \mathrm{~m}^{2}$ section located between the center plants in each plot and on the west side of the row that was collected, dried, and weighed to calculate biomass $/ \mathrm{m}^{2}$. In hand-weeded plots, weeds were removed by hand hoeing throughout the establishment years (2010-12) and on 22 Mar., 10 May, and 19 June in 2013 and 28 Mar., 28 May, 8 July, and 8 Aug. in 2014. The extra day of hoeing in 2014 was needed to compensate for increased weed presence. The weed mat treatment plots were covered in a 1.4-m-wide strip of black, woven polyethylene groundcover (TenCate Protective Fabrics; OBC Northwest Inc., Canby, OR) centered on the row and secured using $0.1-\mathrm{m}$ long nails. According to the manufacturer, the weed mat had a density of $0.11 \mathrm{~kg} \cdot \mathrm{m}^{-2}$ and a water flow rate of $6.8 \mathrm{~L} \cdot \mathrm{h} \cdot \mathrm{m}^{-2}$. The weed mat was placed on top of the row just before planting, and openings were cut for each plant (planting hole). Weeds were removed from the planting hole area and seams in the weed mat, as required, on 31 May 2013 and 10 June and 8 Aug. 2014. Any weeds removed from the hand-weeded and weed mat plots were left between the rows. Labor hours required to maintain the three weed management treatments were recorded.

Irrigation. Each treatment was irrigated with a single lateral of drip tubing (UNIRAM; Netafim USA, Fresno, CA). The tubing had pressure-compensating emitters $\left(1.9 \mathrm{~L} \cdot \mathrm{h}^{-1}\right.$ inline) spaced every $0.6 \mathrm{~m}$ and was placed along the ground at the base of the plants under the weed mat or was attached to a third trellis wire located $0.3 \mathrm{~m}$ above the ground in the nonweeded and hand-weeded plots. The cultivar, irrigation, and weed management treatment combinations were irrigated independently using a manifold with electric solenoid valves and an automatic timer.

Irrigation was scheduled weekly based on the estimates of crop evapotranspiration (ET), but was adjusted as needed each week to maintain similar leaf water potentials
(LWP) among treatments. Crop ET was calculated by multiplying reference ET by a crop coefficient for blackberry that was downloaded daily along with weather data, including air temperature and precipitation, obtained from a Pacific Northwest Cooperative Agricultural Weather Network AgriMet weather station (U.S. Department of the Interior, 2013; Table 1). The weather station was located in a field of tall fescue [Lolium arundinacea (Schreb.) S.J. Darbyshire], $\approx 0.5 \mathrm{~km}$ from the site. Leaf water potential was measured weekly throughout the 2012 2014 seasons after irrigation was started, using a pressure chamber (Model 1000; PMS Equipment, Albany, OR). The measurements were made between 1200 and $1500 \mathrm{HR}$ on one recent fully expanded primocane leaf in three replicate plots per treatment before the postharvest irrigation treatment was implemented and in four replicates thereafter. Irrigation was increased by $10 \%$ above the previous week's rate when mean weekly water potential in a given weed management treatment was lower than the mean of any other weed management treatment in the cultivar. In 2012, LWP was measured only on primocane leaves. Harkins et al. (2013) speculated that a cane type by weed management interaction was responsible for treatment differences seen in fruit characteristics in 2012 so floricane LWP were added in 2013. The interaction was not observed in 2013, so in 2014, only primocane LWP data were collected. Water applications were measured in each treatment using turbine water meters (model 36M201T; Netafim USA) installed in the irrigation manifold. There was no evidence of water runoff during irrigation in any treatment.

Soil water content was measured weekly, beginning after the final fruit harvest and continuing until the rainy season, using a Trase I time domain reflectometry (TDR) system (Soilmoisture Equipment Corp., Santa Barbara, CA). The TDR system was equipped with a pair of 0.4-m stainless steel waveguides and a waveguide connector. The waveguides were installed vertically in the middle of the row between two plants in three replicates of 'Marion' plots receiving no postharvest irrigation, which included all of the training time and weed management combinations. The waveguides were located underneath or next to the drip line and $0.75 \mathrm{~m}$ from two adjacent plants.

Irrigation was applied in the postharvest irrigation treatment from 9 May 2012 to 8 Oct. 2012, 17 May 2013 to 27 Sept. 2013, and 28 May 2014 to 23 Sept. 2014. In the no postharvest irrigation treatment, irrigation was started on the same dates but withheld after the last fruit harvest on 30 July 2012, 19 July 2013, and 15 July 2014. Thus, these latter plots did not receive water other than minimal rainfall until the rainy season began on 12 Oct. 2012, 21 Sept. 2013, and 23 Sept. 2014 (Table 1).

Primocane training. Primocanes in the August-trained treatment were trained to the upper trellis wires on 13-14 Aug. 2012, 27-29 Aug. 2013, and 14 Aug. 2014 using the method described above. In the February-trained 


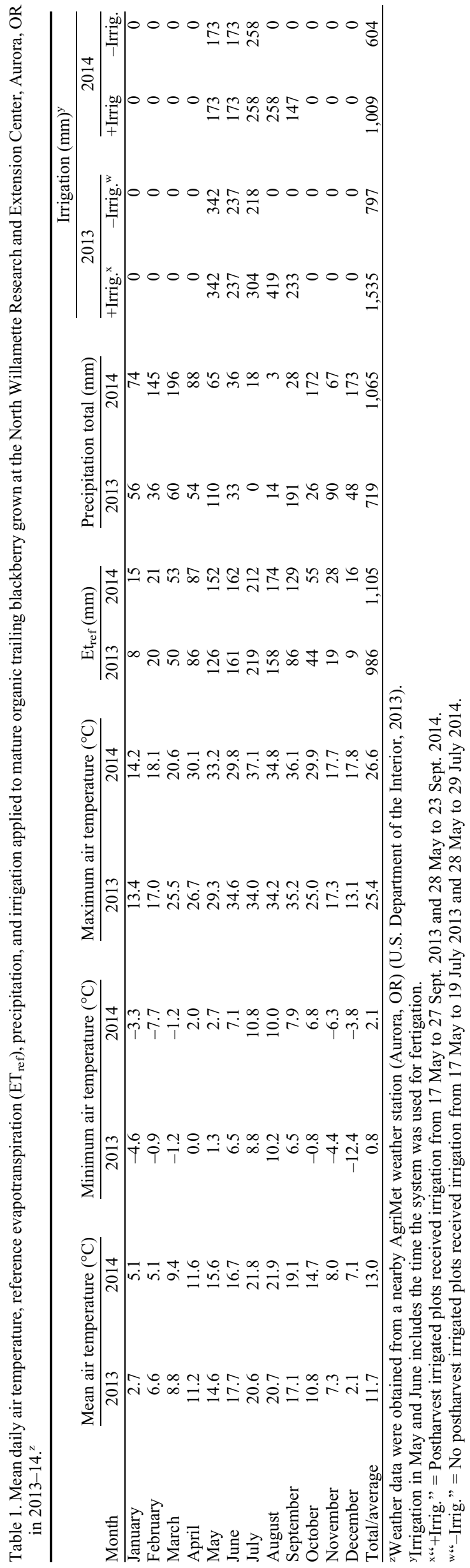

treatment, primocanes were left on the wire for the drip lines, just above ground-level, throughout the growing season and subsequent winter until they were wrapped and tied to the upper two trellis wires on 21-25 Feb. 2013 and 21-28 Feb. 2014. Primocane training was done by replicate to avoid any possible date effects within treatment over the days required to train.

Fertilization. An OMRI-approved fish hydrolysate and fish emulsion blend was diluted $1: 1(\mathrm{v} / \mathrm{v})$ with water and applied through the drip system using a combination of a waterdriven pump fertilizer injector (Mix-Rite 571 CW; DEMA, St. Louis, MO) and an electric, low-volume chemigation pump system (Insectigator III; Agri-Inject, Inc., Yuma, CO). While only one injector was needed, the electric pump was installed to reduce injection time $(\approx 1.5 \mathrm{~h}$ /application compared with $\approx 4.5 \mathrm{~h} /$ application with the water-driven pump). Converted Organics 421 (4N-0.8P0.8K; True Organic Products Inc., Spreckels, CA) was used for the first four applications in 2013 and True Organics 512 (5N-0.4P-1.7K; True Organic Products Inc., Spreckels, CA) was used for the last four applications in 2013 and for all applications in 2014. The fertilizer (s) was split into eight equal applications (about every 2 weeks from 5 Apr. to 12 July 2013 and 19 Mar. to 25 June 2014) and applied at a total rate of $90 \mathrm{~kg} \cdot \mathrm{ha}^{-1} \mathrm{~N}$ per year (based on percentage of $\mathrm{N}$ as stated on the label). Irrigation was run for $30 \mathrm{~min}$ before injection to fully pressurize the system to $303.4 \mathrm{kPa}$ and run for $2 \mathrm{~h}$ after injection to flush the drip lines.

Plant growth and fruit production. Primocanes (at $0.3 \mathrm{~m}$ height) were counted on two separate plants in each four-plant plot on 24 Jan. 2013 (for growth in 2012), 20 Feb. 2014 (for growth in 2013), and 18 Dec. 2014 (for growth in 2014) and average primocanes per plant was calculated. Individual primocanes were defined as originating at the crown or at a branch below $0.3 \mathrm{~m}$ and extending at least to the lower training wire $(1.0 \mathrm{~m})$.

Ripe fruit were harvested twice weekly from 24 June to 18 July in both years, using an overthe-row rotary harvester (Littau Harvesters Inc., Stayton, OR). 'Black Diamond' was harvested on every date in both years whereas 'Marion' was not harvested on the first or last date in either year. Marketable yield and unmarketable fruit (culls, including overripe, damaged, rotten, or underripe fruit) were weighed separately. A subsample of 25 berries was randomly selected from the machine-harvested, marketable yield of each plot and weighed; a weighted average individual fruit weight was calculated for the fruiting season. The subsample was used to measure percent total soluble solids (TSS; ${ }^{\circ}$ Brix) on 5, 8, and 11 July in 2013 and 3, 10, and 15 July in 2014. The subsamples were crushed by hand in a 1-L polyethylene resealable bag, and the juice was used to measure TSS with a temperature-compensated digital refractometer (Atago, Bellevue, WA). A 25berry subsample per treatment plot was shipped overnight to Brookside Laboratories (New Bremen, $\mathrm{OH}$ ) for analysis of fruit percent moisture on 8 July 2013 and 7 July 2014. 
Senescing floricanes were removed by pruning at the base of the plant $(\approx 0.1 \mathrm{~m}$ high) after fruit harvest on 29 July to 5 Aug. in 2013 and 30 July to 1 Aug. in 2014, per standard commercial practice (Strik and Finn, 2012). Two floricanes were randomly selected per plot, and floricane length was measured, and number of nodes per cane, laterals per cane, and fruit per lateral (subsample of 10 laterals) were counted. The number of nodes per plant was calculated by multiplying the canes per plant by the nodes per cane. Percent budbreak was calculated from the nodes per cane and the laterals per cane. The total fresh biomass of the pruned floricanes was determined per plot. A subsample of the pruned canes in each plot was shipped overnight to Brookside Laboratories for analysis of percent moisture content. Dry weight was then calculated. After pruning and data collection, the floricanes were left between the rows and flail mowed (chopped), per standard commercial practice.

During August training in 2013, primocanes were wilted or "flagging" at the cane tip. These canes broke at the crown easily. Larvae were found in these affected canes and identified as raspberry crown borer ( $P$. marginata Harris). The presence of crown borer was assessed in August of both years by counting the number of plots in which at least one infested primocane was discovered when training (broken at base with larval presence identified) or a cane showed symptoms of flagging. The percentage of crown borer infestation was then calculated for each treatment.

An unusually early and extreme cold event for the region occurred in Dec. 2013 (Table 1). Following relatively warm autumn temperatures, the air temperature dropped to $-12.4^{\circ} \mathrm{C}$ on 9 Dec. By Spring 2014, cold damage was evident, based on reduced and delayed budbreak and primocane necrosis. All plots were surveyed for damage on $21 \mathrm{Apr}$. using a rating system, where 1 indicated $100 \%$ of normal budbreak (no visible damage) and 5 indicated extreme damage ( $<5 \%$ of normal budbreak). Plots were rated as an average of the four plants.

Data analysis. Data were analyzed by year due to large differences in the annual weather conditions (Table 1). Within year, data were analyzed as a split-split-split plot design with cultivar as the main plot factor, postharvest irrigation as the split-plot factor, and weed management and training time as split-split plots, using PROC MIXED in SAS (version 9.3; SAS Institute Inc., Cary, NC). Residuals were plotted to assess homogeneity of variance (residual by fitted value plot). When strong fanning was observed in the residual plots, the data were $\log$ transformed before analysis to improve homogeneity of variance and to assess proportional effects. Data were back transformed for presentation. Normality was assessed using a histogram of the residuals. Means from significant effects were compared using a Tukey's honestly significant difference test with $\alpha=0.05$. Mean comparisons from significant interactions were compared using Least Square Means (LS Means) with $\alpha=0.05$.

\section{Results and Discussion}

This study was a continuation of the work done by Harkins et al. (2013) to assess the impact of weed management and cultivar during the establishment years. Our study was conducted in the same planting and implemented the additional treatments of no postharvest irrigation and training time.

Fruit production in 2013. 'Black Diamond' tended $(P=0.08)$ to have greater yield than 'Marion' in 2013 (Table 2). Harkins et al. (2013) also found that 'Black Diamond' had greater yield than 'Marion' during the first year of production in 2012. Total yield declined $\approx 30 \%$ from the first (Harkins et al., $2013)$ to the second fruiting year (2013; Table 2). Yield was relatively high in 2012 because this was the first year in which the plants were cropped, and thus, primocanes grew without competition from floricanes in 2011 (Harkins et al., 2013). In contrast, the primocanes that grew in 2012 competed with a high number of fruiting canes (Harkins et al., 2013), which has been shown to reduce primocane growth (Cortell and Strik, 1997b; Mohadjer et al., 2001). Consequently, 2013 was expected to be a recovery year, in which fruit production on the floricanes would be lower as the planting transitioned to full production every year (Strik and Finn, 2012). Average yield from both cultivars was comparable to what would be expected from a mature, conventionally managed field grown in an every-year production system (Julian et al., 2009).

The nonweeded plots had 100\% weed coverage during the course of this study (data not shown), and the aboveground weed biomass in late June was $25.3 \mathrm{~g} \cdot \mathrm{m}^{-2}$. The hand labor required to control weeds was 81,412 , and $95 \mathrm{~h} / \mathrm{ha}$ in the weed mat, hand-weeded, and nonweeded (to cut off the aboveground biomass before machine harvest) management strategies, respectively. Weed management, on average, improved yield by $54 \%$ over nonweeded plots (Table 2). The weeds in the nonweeded plots were predominantly grasses (E. Dixon, unpublished data), which may have had a more negative impact on the blackberry plants than an intentionally planted nitrogen-fixing cover crop such as clover. Plants grown with weed mat produced a $13 \%$ greater yield than those in handweeded plots (Table 2), similar to the positive impact of weed mat reported by Harkins et al. (2013) and found in erect blackberry and blueberry (Vaccinium corymbosum L.) (Krewer et al., 2009; Makus, 2011; Meyers et al., 2014). Increasing the width of the weed-free strip within the row from 0 to $2 \mathrm{~m}$ also increased yield in erect blackberry (Meyers et al., 2014). Since hand-weeded plots were hoed several times during the season, it is possible that even the relatively young weeds present before each hoeing event competed with the blackberry plants, leading to a reduction in yield.

'Black Diamond' fruit were heavier and contained relatively more water than 'Marion' fruit (Table 2). Average fruit weight was $6 \%$ and $12 \%$ greater for plants grown with weed control than those grown in nonweeded plots for 'Marion' and 'Black Diamond', respectively. Weeds also reduced fruit water content, particularly in 'Black Diamond'. Other studies have demonstrated the negative impact of weeds on fruit weight and fruit water content (Harkins et al., 2013; Meyers et al., 2014). Through 4 years after planting, 'Black Diamond' was not able to compete as effectively with weeds as 'Marion'.

There was a cultivar by training time interaction on fruit water content and TSS. Fruit from February-trained plants contained higher TSS than fruit from plants trained in August, which was likely a concentration effect, as the fruit from the February-trained treatment also had lower water content (Table 2). Fruit TSS was also affected by a three-way interaction among cultivar, irrigation, and weed management (Fig. 1). 'Marion' fruit had higher TSS than 'Black Diamond' for all of the treatment combinations, as reported by others (Fernandez-Salvador et al., 2015a; Harkins et al., 2013). Fruit from both cultivars had the highest TSS in the nonweeded plots, consistent with the findings of Harkins et al. (2013). Meyers et al. (2014) also found that increasing the width of a weed-free strip within the row decreased TSS in erect blackberry. In our study, fruit from the nonweeded plots were smaller and had lower water content, and thus TSS may have been more concentrated; this effect was more pronounced in 'Black Diamond' than in 'Marion' (Fig. 1).

Weeds had a negative effect on many yield components. Plants grown in nonweeded plots had fewer primocanes than those grown with weed control, but there was no effect of weed management on primocane length or the number of nodes per plant, similar to what was observed by Harkins et al. (2013; Table 2). Meyers et al. (2014) found no effect of weeds on primocane length or number in erect blackberry. When primocanes became floricanes, their dry weight at pruning in August was significantly less in nonweeded plots, particularly in 'Black Diamond' (Table 2). There was no significant difference between weed mat and hand-weeded plots for primocane vigor or floricane dry weight (Table 2). Makus (2011) observed increased vigor when erect blackberry were grown with weed mat as compared with bare soil. In our study, there was a cultivar by weed management interaction effect on floricane dry weight because there was a greater reduction in dry weight in nonweeded plots compared with weed mat in 'Marion' (38\%) than in 'Black Diamond' (24\%). Since floricanes were more than twice as long in 'Marion' as in 'Black Diamond' (Table 2), and 'Marion' has thorny canes, there likely was more cane breakage when primocanes were pulled up and trained in the weedy plots. Our findings were similar to those reported by Harkins et al. (2013). 


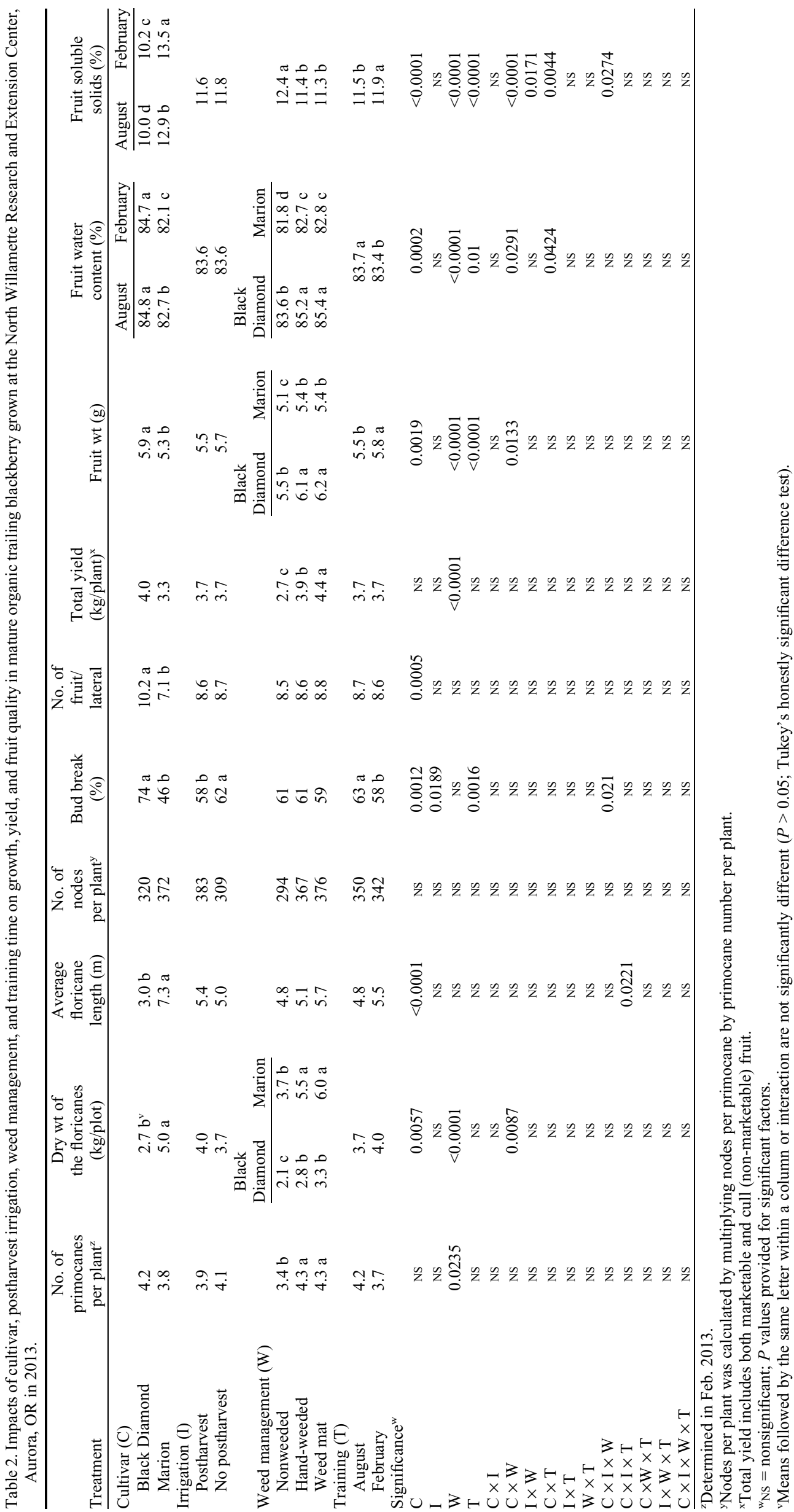



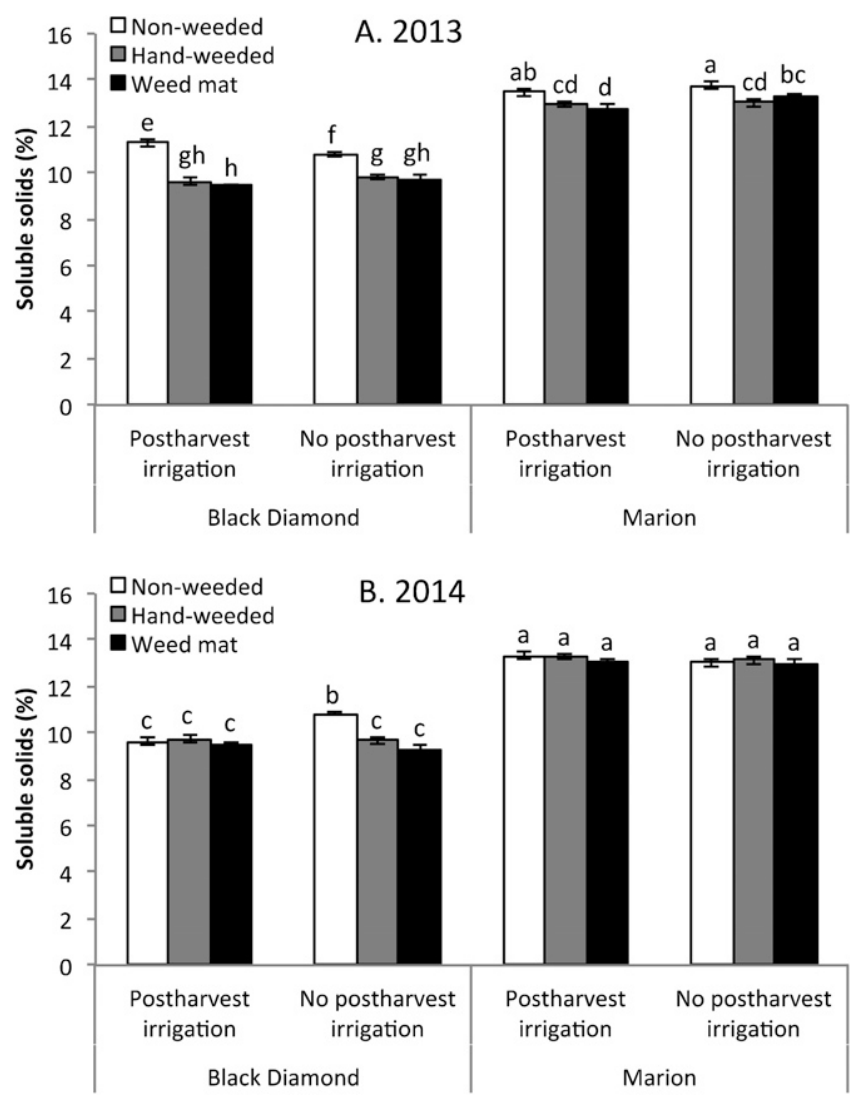

Fig. 1. Effects of cultivar, irrigation, and weed management on fruit soluble solids of 'Black Diamond' and 'Marion' in 2013 (A) and 2014 (B) in mature organic trailing blackberry grown at the North Willamette Research and Extension Center, Aurora, OR. Mean $\pm \mathrm{SE}$; means followed by the same letter within the interaction presented are not significantly different $(P>0.05)$

'Black Diamond' typically has a compact growth habit with densely spaced, short laterals (Fernandez-Salvador et al., 2015a; Finn et al., 2005; Harkins et al., 2013). 'Marion' tends to have more of a sprawling habit with very long canes, low percent budbreak, and long laterals (Fernandez-Salvador, et al., 2015a; Finn et al., 1997; Harkins et al., 2013). In our study, cane length was affected by a cultivar $\times$ irrigation $\times$ training time interaction (Fig. 2). Cane length in 'Black Diamond' was unaffected by training time or postharvest irrigation, whereas 'Marion' canes were shorter when grown without postharvest irrigation and when trained in $\mathrm{Au}-$ gust. August training caused visible signs of stress on the plants, such as wilting, likely a result of the primocanes (next year's floricanes) being sometimes bent or kinked when they were wrapped around the trellis wires and from leaves being torn or ripped off when the primocanes were untangled (E. Dixon, personal observation). Furthermore, August training was done when temperatures were warm (Table 1). More kinking and cane damage would be expected when training the longer, thorny canes of 'Marion' as compared with the shorter, thornless canes of 'Black Diamond'. A significant amount of primocane growth occurs postharvest (Cortell and Strik, 1997b). No postharvest irrigation coupled with the stress of August training led to a shorter cane length in 'Marion' plants in this treatment (Fig. 2; Table 2). In contrast, plants that were irrigated after harvest produced canes of similar length, regardless of training time (Fig. 2).

Percent budbreak on the floricanes was affected by a cultivar $\times$ irrigation $\times$ weed management interaction (Fig. 2). 'Marion' had less budbreak than 'Black Diamond' across all irrigation and weed management treatments. Within a cultivar, long canes tend to have lower budbreak, likely a result of resource limitation in trailing blackberry (Bell et al., 1995a; Cortell and Strik, 1997b). 'Marion' floricanes had the lowest percent budbreak when the primocanes (in the previous year) grew in hand-weeded or weed mat plots with postharvest irrigation, which was likely a response to increased cane length (Fig. 2). Primocanes that were trained in August had greater budbreak in the following spring than those trained in February (Table 2). August-trained primocanes receive better light exposure during fruit bud development (Takeda et al., 2002), which leads to greater budbreak the following spring relative to February training (Bell et al., 1995a). The opposing effects of the cultivar, irrigation, and training time treatments on floricane length and budbreak led to no differences in yield, except for the effect of weed management.

Fruit production in 2014. Yield was affected by every treatment, except irrigation in 2014 (Table 3).'Black Diamond' produced a similar yield in both years of the study, whereas the yield of 'Marion' increased 24\% from 2013 to 2014 when primocanes were February-trained, but declined $12 \%$ for August-trained plants (Tables 2 and 3). Consistent yield from year to year is expected in every-year production systems (Julian et al., 2009), barring any adverse environmental effects such as cold injury. The training time effect in 'Marion' (Table 3) was likely a result of a treatment effect on winter cold damage to canes (see "winter cold injury" below). Augusttrained 'Marion' plants yielded $\approx 1 \mathrm{~kg} /$ plant less than the other cultivar and training time treatment combinations. Commercial producers in Oregon also experienced low 'Marion' yields - there was a $37 \%$ reduction in total 'Marion' yield from 2013 to 2014, while all other cultivars experienced an $8 \%$ increase (U.S. Department of Agriculture, 2015). The low yield in August-trained 'Marion' plants was reflected in a training time effect on several yield components, including fewer primocanes per plant and shorter primocanes relative to those on February-trained plants.

'Black Diamond' produced $60 \%$ of the floricane dry weight of 'Marion' (Table 3), likely a result of 'Marion' producing very long fruiting laterals with large leaves, as discussed previously. 'Black Diamond' floricane dry weight at pruning was unaffected by training time, while 'Marion' floricane dry weight was almost $2 \mathrm{~kg}$ less in Augusttrained plots than in February-trained plots. 'Marion' also produced fruit that weighed less when August-trained compared to Februarytrained plots, contributing to the low yield of this treatment. Training time had an effect on fruit per lateral, with February-trained 'Black Diamond' producing fewer fruit per lateral than the other cultivar and training time combinations. Previous studies have reported between 4.1 and 7.4 fruit/lateral in 'Marion' (Bell et al., 1995a; Cortell and Strik, 1997b; Harkins et al., 2013) and between 5.5 and 10.9 fruit/lateral in 'Black Diamond' (FernandezSalvador et al., 2015a). Bell et al. (1995a) found that 'Marion' had fewer fruit per lateral when February-trained (5.1) than when Augusttrained (6.5), and berry weight was inversely correlated with the number of fruit per lateral. In our study, February-trained 'Black Diamond' plants produced fewer but larger fruit/ lateral than the other treatments. However, we did not find a similar relationship between fruit per lateral and fruit weight across or within cultivars in 2013 (Table 2) or during the establishment years (Harkins et al., 2013).

There was a cultivar by training time interaction on fruit TSS (Table 3). 'Black Diamond' fruit had less TSS than 'Marion' fruit. While there was no effect of training time on 'Marion' fruit TSS, August training resulted in lower fruit TSS than February training in 'Black Diamond'. 'Marion' produced small fruit with low fruit water content, resulting in concentrated TSS. 'Black Diamond' August-trained plants produced smaller fruit than February-trained plants with no effect on fruit water content. This response to August training could be 

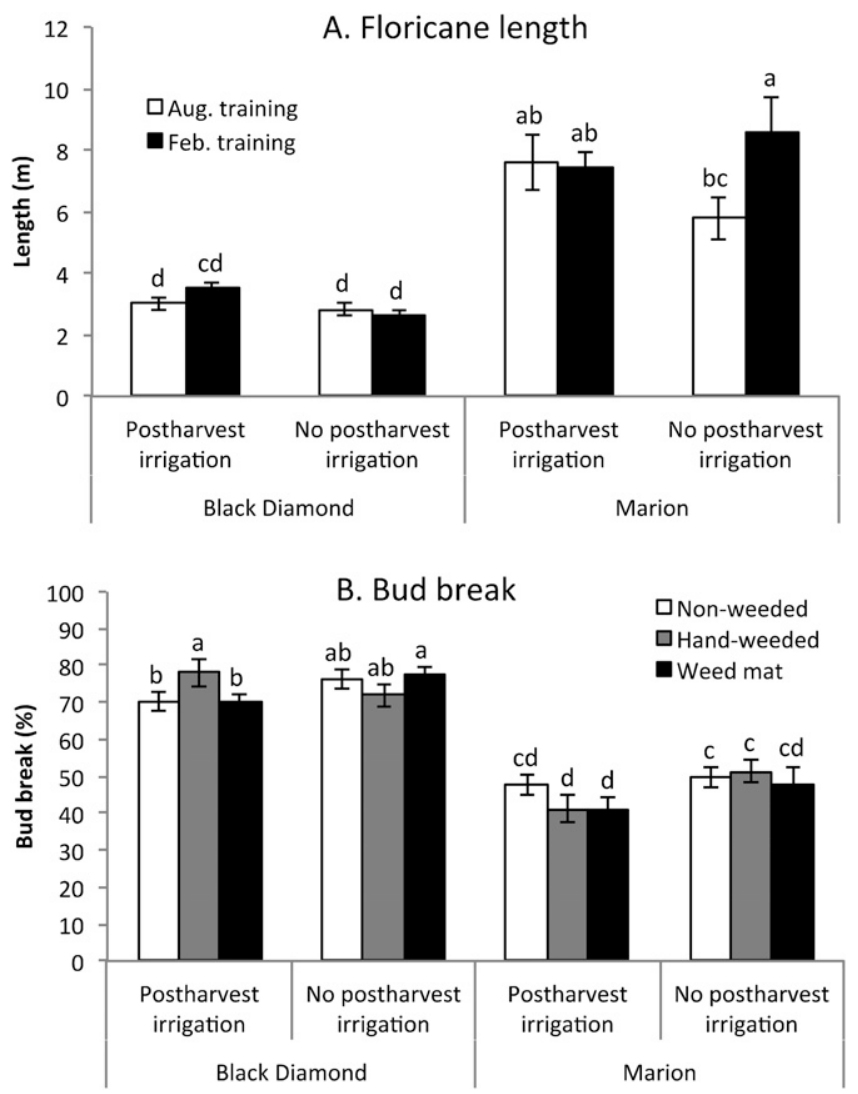

Fig. 2. Effects of cultivar, irrigation, and weed management on floricane length of 'Black Diamond' and 'Marion' (A) and percent budbreak of 'Black Diamond' and 'Marion' (B) in mature organic trailing blackberry grown at the North Willamette Research and Extension Center, Aurora, OR, 2013. Mean \pm $\mathrm{SE}$; means followed by the same letter within the interaction presented are not significantly different $(P>$ $0.05)$.

a disadvantage for fresh market growers, as many small fruit could reduce hand harvest efficiency. However, this is less of an issue for the machine-harvest, processed market.

'Black Diamond' had a longer fruiting season than 'Marion', consistent with what was observed in the prior year (data not shown) and during the establishment year (Harkins et al., 2013), as well as with findings of others (Fernandez-Salvador et al., 2015a). There was also a cultivar by weed management interaction on yield (Table 3). The response of 'Black Diamond' to weed management was similar to what was observed in 2013 and during establishment (Harkins et al., 2013), but the magnitude of the response was greater in 2014. Weed control increased yield by $61 \%$ compared with nonweeded plots in 'Black Diamond' (Table 3). In 'Marion', weed control improved yield by $19 \%$ (Table 3), which was also more than what was observed in 2013 (Table 2). The high yield in weed mat plots was mainly a result of more canes per plant (particularly with February training), a high number of nodes per plant, greater fruit weight (compared with nonweeded), and more floricane biomass per plot (Table 3 ). Archbold et al. (1989) also found that high plant biomass resulted in larger fruit size in semierect blackberry. Interestingly, high yields have been related to several yield components in trailing blackberry, including cane number, cane diameter, cane length, node number, berry size, fruit per lateral, and internode length (Bell et al., 1995a; Cortell et al., 1997b; FernandezSalvador et al., 2015a; Harkins et al., 2013). The most common factors associated with high yield across these studies and in both years of our study appear to be berry weight and cane number per plant. The high yield in our study occurred despite a lower percent budbreak in weed mat plots when primocanes were trained in February.

Weeds reduced fruit weight and percent water content and increased TSS in 2014 (Table 3), as was observed in 2013 (Table 2). Irrigation and training time had an effect on the amount of weed biomass removed from the nonweeded plots before harvest in late June. Plots with postharvest irrigation (in 2013) that were not trained until Feb. 2014 had $10 \mathrm{~g} \cdot \mathrm{m}^{-2}$ less weed biomass than those that were August-trained $(P=0.013$; data not shown). Weed pressure was significantly reduced in February-trained plots because the primocanes lying along the ground from August to February reduced weed growth through shading. This effect was also noticed, although no data were collected, in the hand-weeded plots during the early hoeing dates (E. Dixon, personal observation).

Plots that received no irrigation postharvest for two consecutive years (2012-13) had significantly shorter canes in early 2014 , but this had no effect on yield (Table 3 ). In contrast, in machine-harvested erect blackberry and raspberry, grown in Fayetteville, $\mathrm{AR}$, and Kent, UK respectively, plants that were not irrigated postharvest produced lower yields of smaller berries than plants that were irrigated (Goode and Hyrycz, 1968; Morris et al., 1978). Similar results were found in Arkansas when plants were not irrigated at all in erect blackberry (Morris and Sims, 1985; Sims and Morris, 1982). Morris et al. (1978) also found that irrigation postharvest was necessary for good fruit production the following year. Raspberry plants in Pullman, WA, which received postharvest irrigation produced more fruit per lateral than those that did not, although total yield was not presented (Crandall et al., 1974). In our study, the number of fruit per lateral was unaffected by irrigation. A similar cultivar $\times$ irrigation $\times$ weed management interaction was seen for fruit TSS in 2014 (data not shown) as was described for 2013 (Fig. 1). 'Marion' fruit had a greater TSS than 'Black Diamond' fruit, but TSS in 'Marion' was unaffected by irrigation or training time. In contrast, 'Black Diamond' fruit from nonweeded plots that received no postharvest irrigation had higher TSS than the other treatment combinations. It is not clear why the fruit TSS from nonweeded, postharvest irrigated plots did not follow the same pattern as seen in 2013. Makus (2011) found that erect blackberry grown with weed barriers had higher TSS than those grown on bare soil, a response not observed in our study.

Irrigation. Primocane LWP averaged -0.84 $\mathrm{MPa}$ before fruit harvest when all treatments were being irrigated, but after harvest LWP averaged -0.87 and $-0.96 \mathrm{MPa}$ in the postharvest and no postharvest irrigation treatments, respectively (average of 2012-14; data not shown). This reduction was not significant enough to warrant concern about the water status of the plants. 'Black Diamond' grown without postharvest irrigation had primocanes with lower LWP than those that were irrigated in 2012 and 2013, and there was a larger difference between irrigated and nonirrigated plants than was measured in 'Marion' (Fig. 3). The same trend was seen in 2014, but it was not significant (data not shown). The magnitude of the difference in primocane LWP between 'Marion' and 'Black Diamond' decreased from 2012 to 2014 with no significant difference among cultivars in 2014 (Fig. 4). Although there were some significant differences in primocane LWP between cultivars, weed management treatments, and training times, the differences were $<0.1 \mathrm{MPa}$, and no treatment resulted in a primocane LWP less than $-1.00 \mathrm{MPa}$ in 2013 or 2014.

In 2013, floricane LWP was compared with primocane LWP during the periods before and during fruit harvest when all plots were being irrigated. From 24 May through 19 July, primocane LWP averaged -0.81 $\mathrm{MPa}$ and was higher than floricane LWP $(P<0.0001)$, which averaged $-0.92 \mathrm{MPa}$. Over that same period, there was a time 


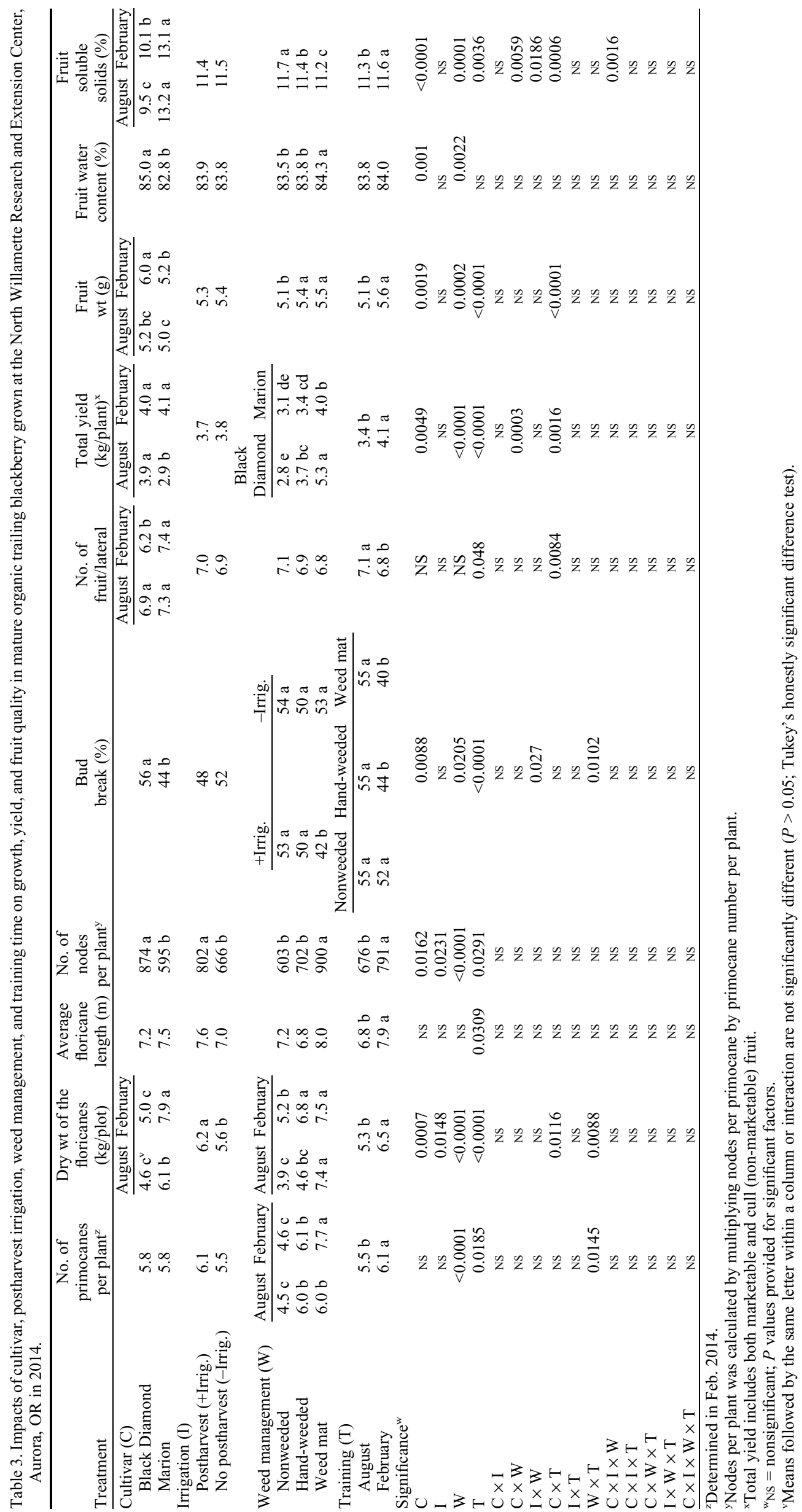


$\times$ cultivar $\times$ cane type interaction that is shown in Fig. 5. Primocane and floricane LWP diverged further once fruit harvest began, especially in 'Marion'. 'Black Diamond' floricane LWP dipped at the onset of harvest, but recovered more than in 'Marion'. These results are consistent with those of Bryla and Strik (2008) and support their hypothesis that primocanes and floricanes are hydraulically independent. Harkins et al. (2013) speculated that competition from weeds may have limited water more in floricanes than in primocanes, resulting in lower fruit water content and higher TSS. However, our study did not find an interaction between cane type and weed management.

Postharvest irrigation did not have a large effect on aboveground vegetative growth. In 2013, the cultivars differed in their response to the postharvest irrigated treatment. 'Black Diamond' floricanes were longer when they had been trained in February (as primocanes), but in 'Marion', primocane training in $\mathrm{Au}$ gust resulted in longer floricanes (Table 2). In 2014, plants that received irrigation postharvest tended to have longer floricanes and had a higher floricane dry weight than those that were not irrigated after harvest (Table 3 ). The greater growth in irrigated plants did not lead to greater yield, indicating that these plants did not require irrigation after harvest for good fruit production. Both cultivars were deeply rooted at the site, and with no

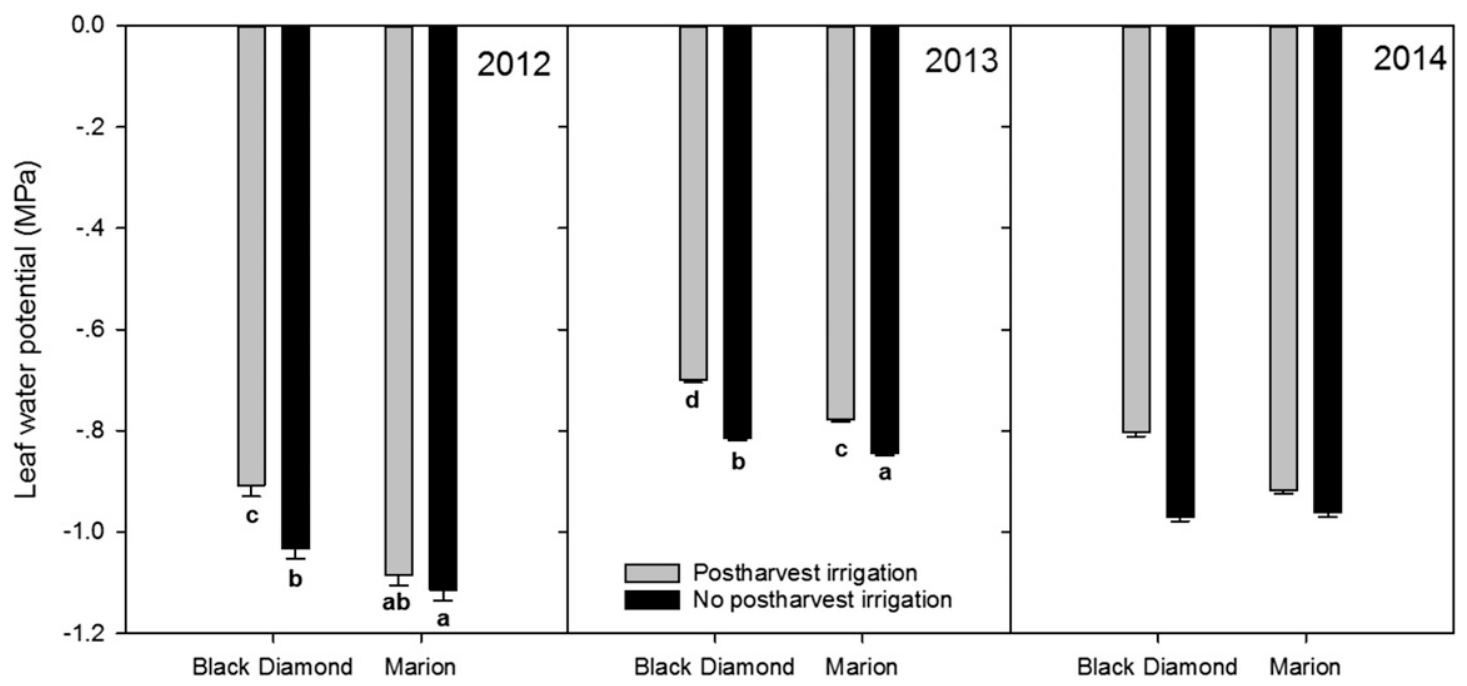

Fig. 3. Effect of cultivar and irrigation on average seasonal primocane leaf water potential of mature organic trailing blackberry grown at the North Willamette Research and Extension Center, Aurora, OR, 2012-2014. Mean \pm SE. Means followed by the same letter within year are not significantly different $(P>0.05)$.

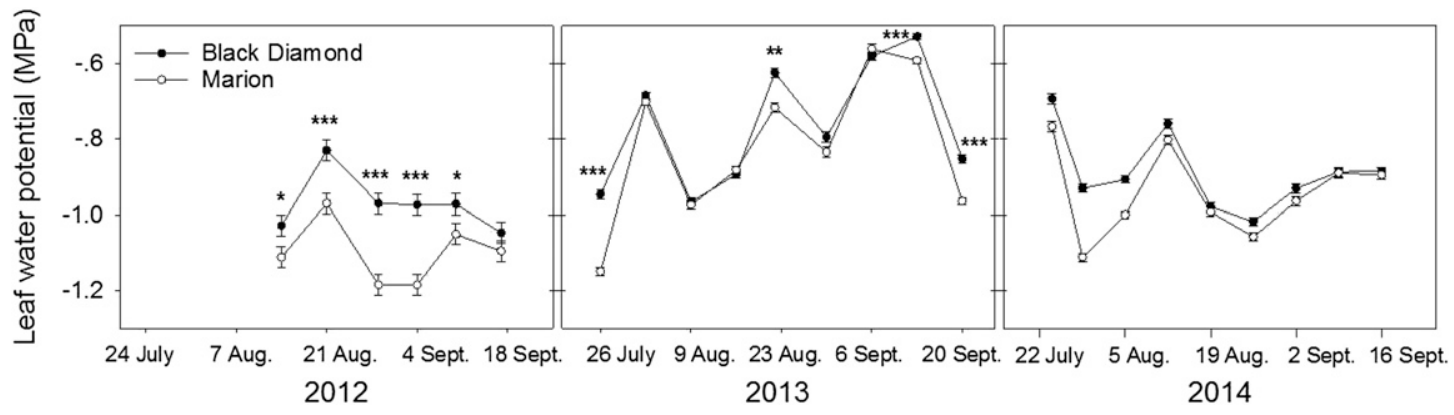

Fig. 4. Effect of cultivar and sample date on primocane leaf water potential of mature organic trailing blackberry grown at the North Willamette Research and Extension Center, Aurora, OR, 2012-2014. Mean \pm SE. Significance provided by sample date $(*=P<0.05 ; * *=P<0.01 ; * * *=P<0.001)$.

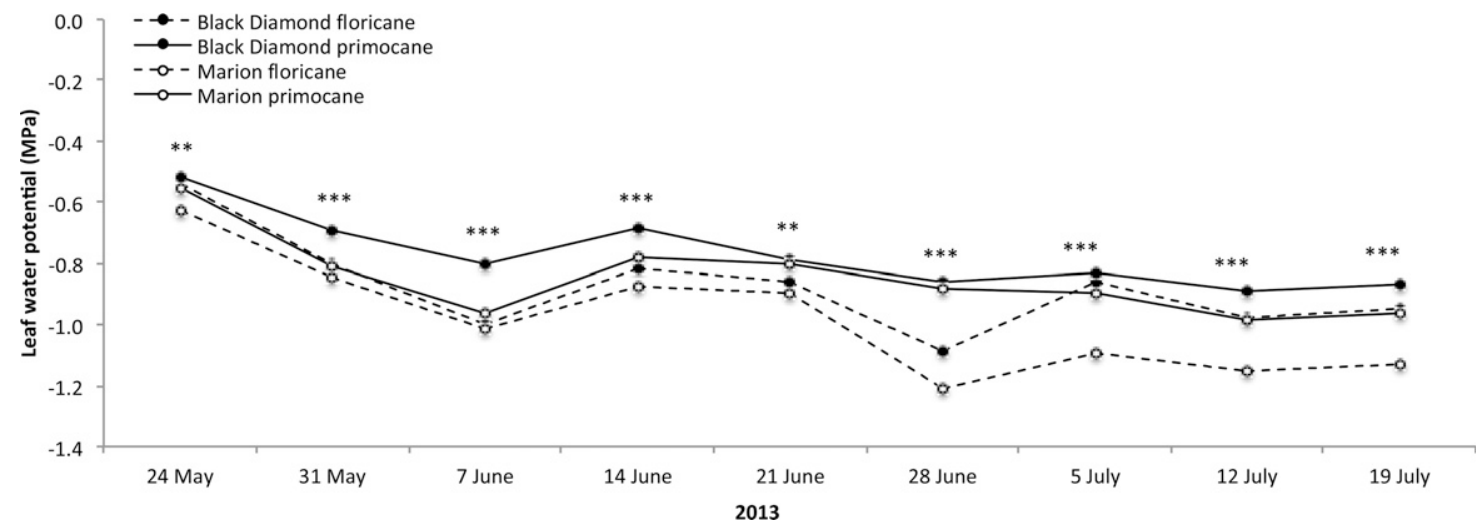

Fig. 5. Effect of cultivar and sample date on primocane and floricane leaf water potential of mature organic trailing blackberry grown at the North Willamette Research and Extension Center, Aurora, OR, 2013. Mean \pm SE. Significance provided by sample date $(*=P<0.05 ; * *=P<0.01 ; * * *=P<0.001)$. 
irrigation after harvest, the plants extracted water down to a soil depth of at least $1.8 \mathrm{~m}$ (L. Valenzuela-Estrada, unpublished data). Peak water use in blackberry occurs during fruit development and declines sharply after harvest (Bryla and Strik, 2008), a response that also occurs in raspberry (Kongsrud, 1976) and blueberry (Bryla and Strik, 2007), and may help explain why such a limited response was seen to no postharvest irrigation in our study.

Soil water content was measured only to a depth of $0.4 \mathrm{~m}$, which was not deep enough to accurately represent blackberry access to water (L. Valenzuela-Estrada, unpublished data). Soil water content in the no postharvest irrigation plots was similar under the three weed management treatments in both years, decreasing throughout the season until it was replenished by a rain event (Table 1; Fig. 6). In 2013, there were significant rain events in August and September. Soil water content tended to be higher under weed mat than the other weed management treatments in both years, but soil water content did not increase as quickly under weed mat after rainfall, indicating that the perforated, polyethylene groundcover is somewhat of a barrier to rain water. Weed mat plots were also much drier than the other treatments when soil samples were collected in October after significant rain (E. Dixon, personal observation). In a study conducted on raspberry establishment, Trinka and Pritts (1992) found that weed mat increased soil moisture compared with hand-weeded or nonweeded treatments, resulting in better growth and higher yield, especially in regards to the nonweeded treatments. They hypothesized that the higher moisture found under the weed mat led to the development of larger root systems and greater growth during establishment, which would then carry over into following years. Further work is needed to determine if there were larger root systems under the weed mat in our study. If so, they may have been responsible for the increased biomass measured aboveground.

Winter cold injury. Many of the treatment effects observed in 2014, which were not present in 2013, were caused by an extreme cold event that occurred in Dec. 2013 (Table 1). 'Marion' is not very cold hardy (Finn et al., 1997) and winter cold injury has been documented in the cultivar during previous cold winters (Bell et al., 1992). 'Marion' buds have been shown to have an $\mathrm{LT}_{50}$ of -5 to $-23{ }^{\circ} \mathrm{C}$, depending on the primocane growing conditions and management (Bell et al., 1995b; Cortell and Strik, 1997a). The air temperature dropped to $-12{ }^{\circ} \mathrm{C}$ in 2013 , within the range of temperatures known to cause damage. The average damage rating for 'Black Diamond' as a result of this cold event was 1.1, essentially no injury (data not shown). In the Pacific Northwest, 'Black Diamond' is considered to be cold hardy, and there have been few reports of winter cold injury since its release (Finn et al., 2005). The yield of 'Black Diamond' was similar in 2013 and 2014 (Tables 2 and 3), confirming there was no winter cold injury. In contrast, 'Marion' plants in all treatments experienced some level of damage (Table 4). 'Marion' plants grown without postharvest irrigation had less damage than those that received irrigation, an effect also seen in raspberry, where plants experiencing a water deficit in the fall had the best winter survival (Hoppula and Salo, 2006). Plants with postharvest irrigation grew later into the fall than those without irrigation and may have not been fully dormant at the time they were exposed to the cold temperature (9 Dec. 2013). However, Bell et al. (1995b) found that sampling date had no effect on hardiness in controlled freezing experiments. Factors that increase vegetative growth in the autumn, such as excessive irrigation, have been found to negatively affect winter survival in raspberry (Hoppula and Salo, 2006; Jennings and Cormack, 1969; Jennings et al., 1972; Säkö and Hiirsalmi, 1980). In our study, 'Marion' plants had the most cold injury when grown in non- and hand-weeded plots and when August-trained. However, when Februarytrained weed mat plots showed more cold injury. Primocanes of plants in Februarytrained, hand-weeded or weed mat plots may have been more vigorous, delaying acclimation relative to those in weedy plots; this may also have increased cold injury. August training stresses the primocanes, as described previously, which may increase risk of cold injury. However, in contrast to February training, where canes are left near the soil surface (a warmer microclimate), August-trained canes are on the trellis throughout the winter and exposed to wind and colder air temperatures. This effect of training time on winter cold injury would explain the yield decline observed in August-trained 'Marion' from 2013 to 2014 compared with the increase that occurred in February-trained plots, as described above. The effect of cold damage on yield of Augusttrained 'Marion' plots can clearly be seen in Fig. 7, where these plots lagged behind the February-trained plots for the entire harvest season. In contrast, 'Black Diamond' had the same progression in yield and cumulative yield, regardless of training time. Bell et al. (1992) observed cold damage in 'Marion' after air temperatures dropped to $-18{ }^{\circ} \mathrm{C}$ in Dec. 1991. Fields that had been trained in August that year had twice the number of dead canes as those trained in February. In addition, yield declined by $43 \%$ in August-trained fields compared with $36 \%$ in February-trained fields (Bell et al., 1992).

Crown borer. Raspberry crown borer has a 2-year life cycle in Oregon. Eggs are laid singularly on the underside margins of leaves

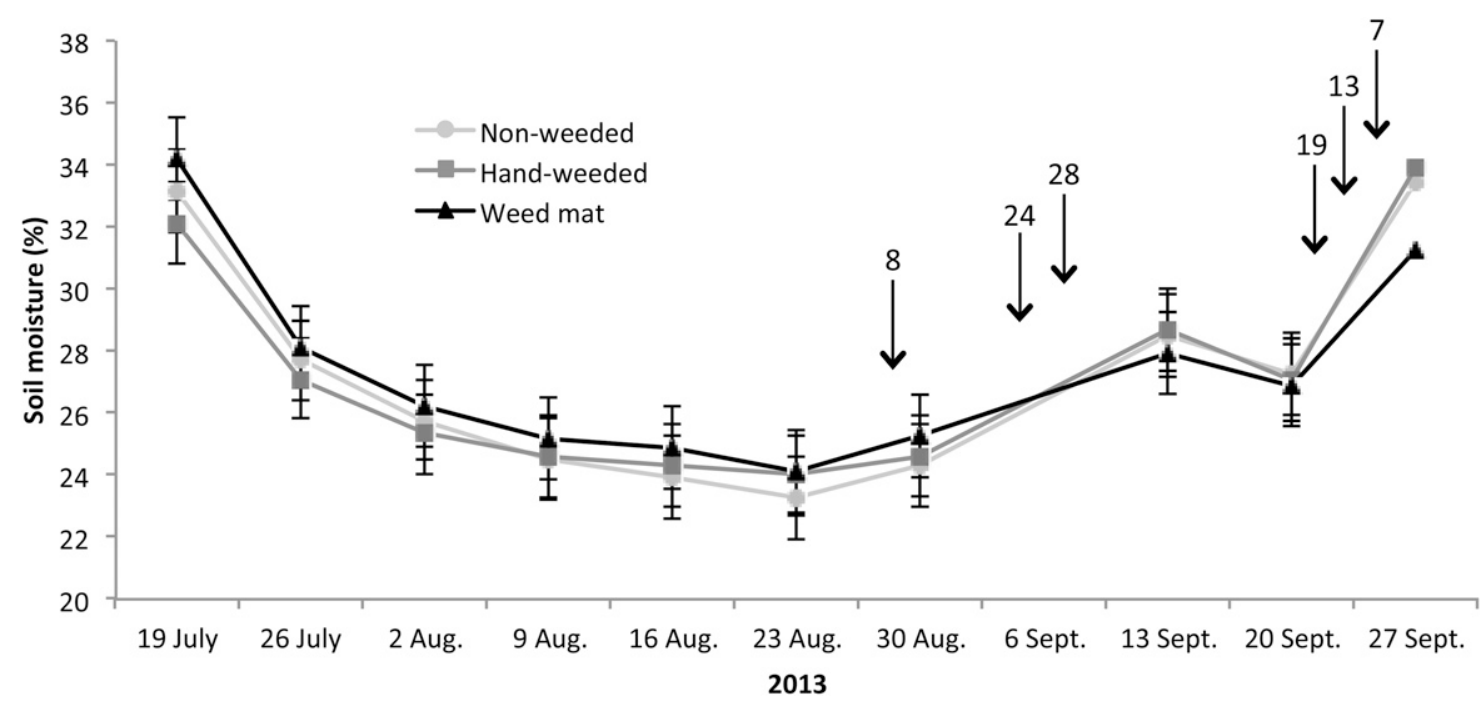

Fig. 6. Effect of weed management and sample date on soil water content in mature organic trailing blackberry not irrigated postharvest and grown at the North Willamette Research and Extension Center, Aurora, OR, in 2013. Measurements were taken weekly (beginning after fruit harvest and continuing until the rainy season) at a depth of $0-0.4 \mathrm{~m}$ in plots with no postharvest irrigation. Rain events that resulted in $>5 \mathrm{~mm}$ of accumulation are indicated with arrows and the volume $(\mathrm{mm})$ of the event. Mean $\pm \mathrm{SE}$. 
Table 4. Impact of postharvest irrigation, weed management, and training time (August or February) on cold injury sustained in mature 'Marion' organic trailing blackberry grown at the North Willamette Research and Extension Center, Aurora, OR after exposure to damaging cold temperatures in Dec. 2013.

\begin{tabular}{|c|c|c|}
\hline Treatment & \multicolumn{2}{|c|}{ Rating $^{2}$} \\
\hline \multicolumn{3}{|l|}{ Irrigation (I) } \\
\hline Postharvest & \multicolumn{2}{|c|}{$2.5 \mathrm{a}^{\mathrm{x}}$} \\
\hline No postharvest & \multicolumn{2}{|c|}{$1.9 \mathrm{~b}$} \\
\hline Weed management (W) & August & February \\
\hline Nonweeded & $3.1 \mathrm{a}$ & $1.5 \mathrm{c}$ \\
\hline Hand-weeded & $2.7 \mathrm{a}$ & $1.9 \mathrm{bc}$ \\
\hline Weed mat & $1.9 \mathrm{bc}$ & $2.1 \mathrm{~b}$ \\
\hline \multicolumn{3}{|l|}{ Training (T) } \\
\hline August & \multicolumn{2}{|c|}{$2.5 \mathrm{a}$} \\
\hline February & \multicolumn{2}{|c|}{$1.8 \mathrm{~b}$} \\
\hline \multicolumn{3}{|l|}{ Significance $^{\mathrm{y}}$} \\
\hline I & \multicolumn{2}{|c|}{0.0007} \\
\hline W & \multicolumn{2}{|c|}{ NS } \\
\hline $\mathrm{T}$ & \multicolumn{2}{|c|}{$<0.0001$} \\
\hline $\mathrm{I} \times \mathrm{W}$ & \multicolumn{2}{|c|}{ NS } \\
\hline $\mathrm{I} \times \mathrm{T}$ & \multicolumn{2}{|c|}{ NS } \\
\hline $\mathrm{W} \times \mathrm{T}$ & \multicolumn{2}{|c|}{0.0001} \\
\hline $\mathrm{I} \times \mathrm{W} \times \mathrm{T}$ & \multicolumn{2}{|c|}{ NS } \\
\hline
\end{tabular}

${ }^{\mathrm{z}} \mathrm{A}$ higher rating indicates more cold damage. $1=$ normal budbreak (no visible damage), 2 = light damage $(75 \%$ of normal budbreak), $3=$ moderate damage ( $50 \%$ of normal), $4=$ heavy damage $(25 \%$ of normal), $5=$ extreme damage $(<5 \%$ of normal budbreak). Plots were rated based on the average damage of the four plants on 21 Apr. 2014.

${ }^{\mathrm{y}_{\mathrm{NS}}}=$ nonsignificant; $P$ values are provided for significant factors

${ }^{\mathrm{x}}$ Means followed by the same letter within a column or interaction are not significantly different $(P>0.05$; Tukey's honestly significant difference test).

during August and September and hatch in 40 to $60 \mathrm{~d}$, at which point, the larvae crawl down the cane and bore into the crown of the plant and overwinter. They spend the next growing season tunneling through the crown and the base of the new primocanes and, then, overwinter again, to emerge as adults in the next summer (Breakey, 1963; Raine, 1962). Because of their 2-year lifecycle, an infestation may go unnoticed in the field until it is relatively severe. Crown borer can be a serious pest in blackberry. In severe infestations, $30 \%$ of plants may be lost (Lovett, 1921). In organic production, where options for pest control are limited, the recommended control method for raspberry crown borer is removing and burning infested plants (DeFrancesco et al., 2015). A sex pheromone component for raspberry crown borer has recently been developed and was successful in capturing males in wing traps (Judd et al., 2012; Teasdale et al., 2013). In our study, wing traps with the pheromone bait (Evergreen Growers Supply, Clackamas, OR) were deployed during the second year, as per the recommendations by Teasdale et al. (2013). However, no adult crown borers were captured, despite the presence of the larvae in the field.

Although statistical analysis for this damage was not possible with these data, clear trends were apparent (Table 5). 'Black Diamond' was affected by this insect pest during the study and 'Marion' was not. It is possible that the thornless canes and dark green foliage found in this cultivar are more attractive to the pest than the thorny canes and lighter green leaves found in 'Marion'. Interestingly, Breakey (1963) found that crown borer had no cultivar preference in several studies done in red raspberry in Washington. Although August-trained plots appeared to be more heavily infested than February-trained plots (Table 5), data were collected during August training, which probably caused bias (as the plots that were to be February-trained still had canes on the ground, making it more difficult to observe canes for symptoms of crown borer infestation). Plots receiving postharvest irrigation had about half the incidence of crown borer as those that were not irrigated. The reason for this positive response to postharvest irrigation is unclear. Nonweeded plots also had a reduced presence of crown borer when compared with plots receiving weed control. Weed cover may provide habitat for beneficial insects or predators of the crown borer.

On the basis of our results, it is not clear what effect the crown borer infestation had on growth and yield of 'Black Diamond'. The infestation may have been present in the field earlier but was not discovered, which may have also had an effect on the relatively low numbers of crown borer seen in 2014. The low temperatures in Dec. 2013 also probably had an effect on the crown borer, but the cold tolerance of this pest is not known. Alternateyear production should be considered as a cultural method of reducing crown borer pressure, as all canes would be removed every 2 years, perhaps disrupting the lifecycle of the pest.

\section{Conclusions}

Withholding irrigation after harvest saved an estimated 1 million L.ha ${ }^{-1}$ over the 2 years of the study (Table 1). Goode and Hyrycz (1968) also found that deficit irrigation after harvest was an effective method to reduce water requirements in raspberry. In this case, raspberry plants irrigated only once during fruit expansion performed just as well as those irrigated throughout the season. Such reductions in irrigation after harvest in blackberry could result in considerable water and energy savings, as well as in environmental benefits. However, additional research is needed to verify that the plants in nonirrigated plots were not getting water from irrigated plots in adjacent rows (although this was unlikely as plants were drip irrigated and there was no relationship between subplot location in the field and yield) and to ensure that similar effects would be seen in a heavy cropping year or in other cultivars and soil types.

The impacts of weed management, when considered across the mature years of this study and the establishment years (Harkins et al., 2013), indicate that weed control is critically important for good blackberry production, and no weeding is a poor management option. Blackberry plants in the nonweeded treatment consistently produced fewer canes, less biomass, and a lower yield of lighter fruit than in either weed control treatment. In addition, plants grown with weed mat often produced more biomass and had a greater yield than those that were handweeded, consistent with Harkins et al. (2013). Weed mat is, thus, an effective and economical (Harkins et al., 2013) method of weed control in this type of blackberry.

Although August training has been shown to increase yield in 'Marion' (Bell et al., 1995a; Sheets et al., 1972), this response was not observed in our study. August-trained plants produced the same yield as Februarytrained plants in 2013. In 2014, while training time did not affect yield in 'Black Diamond',

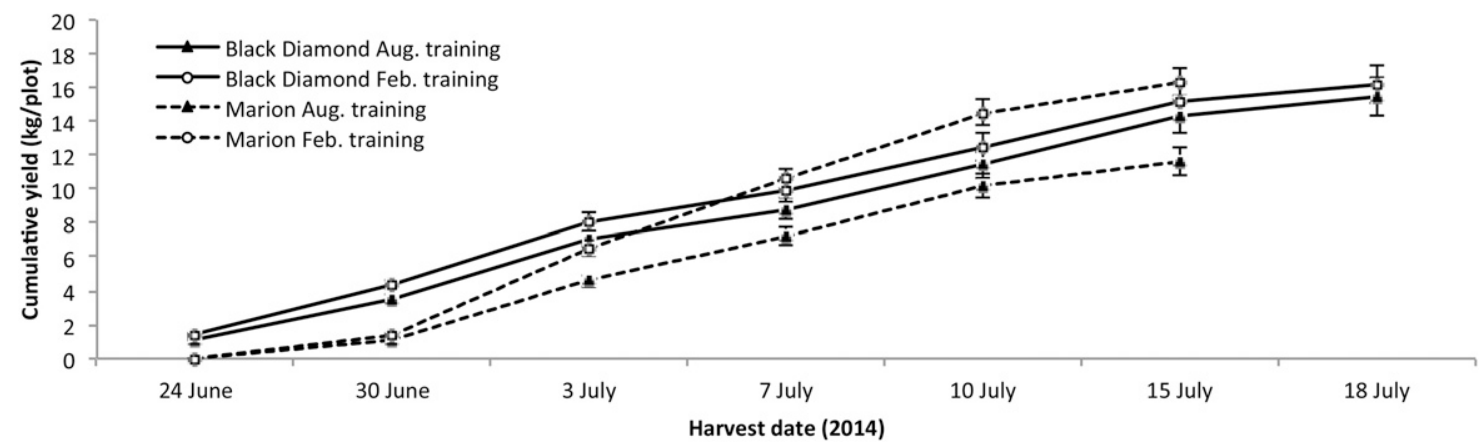

Fig. 7. Effect of cultivar and training time on cumulative yield of mature organic trailing blackberry grown at the North Willamette Research and Extension Center, Aurora, OR, 2014. Mean \pm SE. 
Table 5. Impact of cultivar, postharvest irrigation, weed management, and training time on raspberry crown borer (Pennisetia marginata Harris) infestation in mature organic trailing blackberry grown at the North Willamette Research and Extension Center, Aurora, OR. ${ }^{\mathrm{z}}$

\begin{tabular}{|c|c|c|c|}
\hline \multirow[b]{2}{*}{ Treatment } & \multicolumn{3}{|c|}{ Plots infested by crown borer $(\%)^{\mathrm{y}}$} \\
\hline & 2013 & 2014 & Total \\
\hline \multicolumn{4}{|l|}{ Cultivar } \\
\hline Black Diamond & 30 & 7 & 37 \\
\hline Marion & 0 & 0 & 0 \\
\hline \multicolumn{4}{|l|}{ Irrigation } \\
\hline Postharvest & 8 & 3 & 11 \\
\hline No postharvest & 22 & 3 & 25 \\
\hline \multicolumn{4}{|l|}{ Weed management } \\
\hline Nonweeded & 10 & 0 & 10 \\
\hline Hand-weeded & 20 & 5 & 25 \\
\hline Weed mat & 15 & 5 & 20 \\
\hline \multicolumn{4}{|l|}{ Training } \\
\hline August & 17 & 7 & 24 \\
\hline February & 13 & 0 & 13 \\
\hline
\end{tabular}

${ }^{\mathrm{z}}$ Data collected during August training. Plots found during training in Feb. 2013 indicate equal presence in August- and February-trained plots.

yPercent of plots in each treatment where crown borer larvae were discovered or suspected in at least one cane during August training.

there was more cold injury and less yield when 'Marion' was August-trained. The results of training time may not be conclusive in this study because 2013 was a low-yield year, and 2014 was unusual because of winter injury. However, August training appears to be risky in 'Marion' and is, thus, not recommended for organic production. In addition, February training was an advantage in both cultivars for reduced weed pressure in the hand-weeded plots. Our study also showed that production systems that promote late-season growth such as weed mat and postharvest irrigation increased winter cold injury.

Further study is needed to develop effective organic control of the raspberry crown borer. Since there seems to be significant differences in cultivar attractiveness or susceptibility, cultivar selection might be one of the most important tools. Other cultural tools, such as alternate-year production and early scouting, may also be effective. There has been some work done with biological control agents, although complete control was not achieved (Capinera et al., 1986; McKern et al., 2007). There is also a need for further work with pheromone trapping, as the available lure was ineffective in our study.

Contrary to previous work (FernandezSalvador et al., 2015a; Harkins et al., 2013), 'Black Diamond' did not produce a higher yield than 'Marion' in 2013, and in 2014, only produced higher yield under optimal weed management and when 'Marion' had been damaged by winter cold injury. Weeds caused a much greater reduction in yield in 'Black Diamond' than in 'Marion', so it is possible that 'Black Diamond' grown under ideal conditions in this production system (i.e., with weed mat) would outperform 'Marion' over time. Interestingly, conventional blackberry fields are expected to yield $3.5 \mathrm{~kg} /$ plant (Julian et al., 2009). In our study, the best treatment combinations yielded between 4 and $5 \mathrm{~kg}$ of fruit per plant in both years, indicating that high yields are possible in organic blackberry production, provided the weeds are controlled.

\section{Literature Cited}

Archbold, D.D., J.G. Strang, and D.M. Hines. 1989. Yield component responses of hull thornless blackberry to nitrogen and mulch. HortScience 24:604-607.

Bell, N., E. Nelson, B. Strik, and L. Martin. 1992. Assessment of winter injury to berry crops in Oregon, 1991. Agr. Expt. Sta. Spec. Rpt. 902, Oregon State Univ., Corvallis, OR.

Bell, N.C., B.C. Strik, and L.W. Martin. 1995a Effect of primocane suppression date on 'Marion' trailing blackberry. I. Yield components. J. Amer. Soc. Hort. Sci. 120:21-24.

Bell, N.C., B.C. Strik, and L.W. Martin. 1995b. Effect of primocane suppression date on 'Marion' trailing blackberry. II. Cold hardiness. J. Amer. Soc. Hort. Sci. 120:25-27.

Breakey, E.P. 1963. Biology and control of the raspberry crown borer Bembecia marginata (Harris). Wash. Agric. Exp. Sta. Tech. Bull. 39.

Bryla, D.R. and B.C. Strik. 2007. Effects of cultivar and plant spacing on the seasonal water requirements of highbush blueberry. J. Amer. Soc. Hort. Sci. 132:270-277.

Bryla, D.R. and B.C. Strik. 2008. Do primocanes and floricanes compete for soil water in blackberry? Acta Hort. 777:477-482.

Capinera, J.L., W.S. Cranshaw, and H.G. Hughes. 1986. Suppression of raspberry crown borer, Pennisetia marginata (Harris) (Lepidoptera: Sesiidae) with soil applications of Steinernema feliae (Rhabditida: Steinernematidae). J. Invertebr.

Cortell, J.M. and B.C. Strik. 1997a. Effect of floricane number in 'Marion' trailing blackberry. I. Primocane growth and cold hardiness. J. Amer. Soc. Hort. Sci. 122:604-610.

Cortell, J.M. and B.C. Strik. 1997b. Effect of floricane number in 'Marion' trailing blackberry. II. Yield components and dry mass partitioning. J. Amer. Soc. Hort. Sci. 122:611-615.

Crandall, P.C., D.F. Allmendinger, J.D. Chamberlain, and K.A. Biderbost. 1974. Influence of cane number and diameter, irrigation, and carbohydrate reserves on the fruit number of red raspberries. J. Amer. Soc. Hort. Sci. 99:524-526.

DeFrancesco, J., B. Edmunds, and N. Bell. 2015. Cane fruit pests: Raspberry crown borer. In: C. Pathol. 48:257-258.
S. Hollingsworth (ed.). Pacific northwest insect management handbook [online]. Oregon State University, Corvallis, OR. 4 Apr. 2015. <http:// insect.pnwhandbooks.org/small-fruit/cane-fruit/ cane-fruit-raspberry-crown-borer>.

Goode, J.E. and K.J. Hyrycz. 1968. The response of Malling Jewel and Malling Exploit raspberries to different soil moisture conditions and straw mulching. J. Hort. Sci. 43:215-230.

Fernandez-Salvador, J., B.C. Strik, and D.R. Bryla. 2015a. Liquid corn and fish fertilizers are good options for fertigation in blackberry cultivars grown in an organic production system. HortScience 50:225-233.

Fernandez-Salvador, J., B.C. Strik, Y. Zhao, and C.E. Finn. 2015b. Trailing blackberry genotypes differ in yield and postharvest fruit quality during establishment in an organic production system. HortScience 50:240-246.

Finn, C., B. Strik, and F.J. Lawrence. 1997. 'Marion' trailing blackberry. Fruit Var. J. 51:130-133.

Finn, C.E., B.M. Yorgey, B.C. Strik, H.K. Hall, R.R. Martin, and M. Qian. 2005. 'Black Diamond' thornless trailing blackberry. HortScience 40:2175-2178.

Harkins, R.H., B.C. Strik, and D.R. Bryla. 2013. Weed management practices for organic production of trailing blackberry: I. Plant growth and early fruit production. HortScience 48:11391144.

Harkins, R.H., B.C. Strik, and D.R. Bryla. 2014. Weed management practices for organic production of trailing blackberry: II. Accumulation and loss of biomass and nutrients. HortScience 49:35-43.

Hoppula, K.I. and T.J. Salo. 2006. Effect of irrigation and fertilization methods on red raspberry winter survival. Acta Agriculturae Scandinavica Section B-Soil and Plant Science 56:60-64.

Jennings, D.L. and M.R. Cormack. 1969. Factors affecting the water content and dormancy of overwintering raspberry canes. Hort. Res. 9:18-25.

Jennings, D.L., E. Carmichael, and J.J. Costin. 1972. Variation in the time of acclimation of raspberry canes in Scotland and Ireland and its significance for hardiness. Hort. Res. 12:187-200.

Judd, G.J.R., R. Gries, C. Teasdale, and G. Gries. 2012. Identification of a sex pheromone component for Pennisetia marginata (Lepidoptera: Sesiidae). Can. Entomol. 144:798-807.

Julian, J.W., C.F. Seavert, B.C. Strik, and D. Kaufman. 2009. Berry economics: Establishing and producing Marion blackberries in the Willamette Valley. Ore. State Univ. Ext. Serv. EM8773, Corvallis, OR.

Kongsrud, K.L. 1976. Drought effects on raspberries at different times of the growing season. VI. Summary. Forskning og Forsok i Landbruket. 27:73-83.

Krewer, G., M. Tertuliano, P. Andersen, O. Liburd, G. Fonsah, H. Serri, and B. Mullinix. 2009. Effect of mulches on the establishment of organically grown blueberries in Georgia. Acta Hort. 810:483-488.

Kuepper, G.L., H. Born, and J. Bachmann. 2003. Organic culture of bramble fruits. Horticultural production guide. Appropriate Technol. Transfer Rural Areas, IP022. Butte, MT.

Lovett, H.A. 1921. The loganberry crown borer, Bembecia marginata (Harris), p. 199-120. In: Third Crop Pest and Hort. Report. Ore. Agric. Exp. Sta. 1915-1920. Corvallis, OR.

Makus, D.J. 2011. Use of synthetic ground covers to control weeds in blackberries. Intl. J. Fruit Sci. 11:286-298.

McKern, J.A., D.T. Johnson, and B.A. Lewis. 2007. Biology and control of the raspberry crown 
borer (Lepidoptera: Sesiidae). J. Econ. Entomol. 100:398-403.

Meyers, S.L., K.M. Jennings, D.W. Monks, and W.E. Mitchem. 2014. Effect of weed-free strip width on newly established 'Navaho' blackberry growth, yield, and fruit quality. Weed Technol. 28:426-431.

Mohadjer, P., B.C. Strik, B.J. Zebarth, and T.L. Righetti. 2001. Nitrogen uptake, partitioning and remobilization in 'Kotata' blackberry in alternate-year production. J. Hort. Sci. Biotechnol. 76:700-708.

Morris, J.R., G.S. Nelson, A.A. Kattan, and D.L. Cawthon. 1978. Developing a mechanized harvesting and production system for erect blackberries. HortScience 13:228-235.

Morris, J.R. and C.A. Sims. 1985. Effects of cultivar, soil moisture, and hedge height on yield and quality of machine-harvested erect blackberries. J. Amer. Soc. Hort. Sci. 110:722-725.

Raine, J. 1962. Life history and behaviour of the raspberry crown borer Bembecia marginata (Harr.) (Lepidoptera: Aegeriidae). Can. Entomol. 94:1216-1222.

Säkö, J. and H. Hiirsalmi. 1980. Winterhardiness and productivity of the red raspberry in Finland. Acta Hort. 112:221-227.

Sheets, W.A., R.M. Bullock, and R. Garren, Jr. 1972. Effects of plant density, training, and pruning on blackberry yield. J. Amer. Soc. Hort. Sci. 97:262-264.

Sims, C.A. and J.R. Morris. 1982. Effects of cultivar, irrigation, and ethephon on the yield, harvest distribution, and quality of machineharvested blackberries. J. Amer. Soc. Hort. Sci. 107:542-547.

Strik, B.C. and G. Buller. 2002. Reducing thorn contamination in machine harvested 'Marion' blackberry. Acta Hort. 585:677-681.

Strik, B.C., J.R. Clark, C.E. Finn, and M.P. Bañados. 2008. Worldwide production of blackberries. Acta Hort. 777:209-217.

Strik, B.C. and C.E. Finn. 2012. Blackberry production systems - A worldwide perspective. Acta Hort. 946:341-348.

Takeda, F., B.C. Strik, D. Peacock, and J.R. Clark. 2002. Cultivar differences and the effect of winter temperature on flower bud development in blackberry. J. Amer. Soc. Hort. Sci. 127:495-501.

Teasdale, C., G.J.R. Rudd, R. Gries, and G. Gries. 2013. Evaluation of synthetic sex pheromone for monitoring and management of raspberry crown borer Pennisetia marginata (Lepidoptera: Sesiidae). Agr. For. Entomol. 15:285-293.

Trinka, D.L. and M.P. Pritts. 1992. Micropropagated raspberry plant establishment responds to weed control practice, row cover use, and fertilizer placement. J. Amer. Soc. Hort. Sci. 117:874-880.
U.S. Department of Agriculture. 2013. Berry release. Washington and Oregon berry crops: Acres, yield, production, price, and value, 2010-2012. U.S. Dept. Agr., Natl. Agr. Statistical Ser., Washington, DC.

U.S. Department of Agriculture. 2015. Blackberry area harvested, yield, production, utilization, price and value by variety-Oregon: 20122014. In: NW noncitrus fruits and nuts 2014 preliminary press release. U.S. Dept. Agr., Natl. Agr. Statistical Serv., Washington, DC. 2 Apr. 2015. <http://www.nass.usda.gov/ Statistics_by_State/Oregon/Publications/Fruits_ Nuts_and_Berries/FRT1_1.pdf $>$.

U.S. Department of Agriculture. 2014. Table 33: Berries: 2012 and 2007. In: 2012 Census of Agriculture. U.S. Dept. Agr., Natl. Agr. Statistical Serv., Washington, DC.

U.S. Department of Agriculture. 2010. Table 6: Organic berries harvested from certified and exempt organic farms: 2008. In: Organic production survey (2008), 2007 Census of agriculture. U.S. Dept. Agr., Natl. Agr. Statistical Serv., Washington, DC.

U.S. Department of the Interior. 2013. U.S. Department of the Interior, Bureau of Reclamation, AgriMet. Boise, ID. 5 Apr. 2015. <http:// www.usbr.gov/pn>. 